\title{
Lucrecia y Virginia como prototipos virtuosos de feminidad en la Antigua Roma: estereotipos para una educación diferenciada*
}

\author{
Lucretia and Verginia as virtuous prototypes of femininity in \\ Ancient Rome: stereotypes for a differentiated education
}

\section{Pedro David Conesa Navarro*}

\begin{abstract}
Resumen: En este trabajo pretendemos mostrar la importancia que Lucrecia y Virginia tuvieron para la formación de los roles femeninos en la Antigua Roma. Las muertes de estas mujeres virtuosas fueron vistas como prototipos femeninos, pues el honor familiar estaba por encima de los intereses particulares. No sería hasta la irrupción del cristianismo cuando sus muertes fueron criticadas. Además de repasar dichos relatos, también nos interesaremos por la educación predeterminada que tenían las mujeres, fieles al ámbito doméstico como cuidadoras del hogar, madres y fieles esposas.
\end{abstract}

\begin{abstract}
In this paper, we are tring to show the importance that Lucretia and Vergina had for the formation of the gender roles in the Ancient Rome. The deaths of these virtuous women were seen as female prototypes, because the family honor was above private interests. It would not be until the irruption of Christianity when their deaths would be criticized. In addition to reviewing these stories, we will also be interested in the predetermined education that women had, faithful to the domestic sphere as caretakers of the home, mothers and faithful wives.
\end{abstract}

Palabras-clave:

Lucrecia;

Virginia;

Honor familiar;

Educación romana.

\section{Keywords:}

Lucretia;

Verginia;

Family honor;

Roman education.

\footnotetext{
* Este trabajo ha sido posible gracias a la concesión de un Contrato Predoctoral FPI de la Fundación Séneca. Agencia Territorial de Ciencia y Tecnología de la Región de Murcia (19829/FPI/15). Miembro del Grupo de Investigación ARHIS (Arqueología Histórica y Patrimonio del Mediterráneo Occidental) (E041-08) de la Universidad de Murcia, cuyo investigador principal es el Dr. José Miguel Noguera Celdrán.

** Doctorando de la Universidad de Murcia y de la Università degli Studi di Roma-Tor Vergata.
} 


\section{Introducción}

Viajero, lo que digo es poco, detente y léetelo todo. Aquí está el no bello sepulcro de una bella mujer.

Sus padres la llamaron Claudia.

Amó a su marido con todo su corazón.

Dos hijos engendró a uno lo deja en tierra y bajo tierra sepulta al otro.

De conservación encantadora a la vez que andar elegante.

Veló por su casa. Tejió lana.

He dicho, Márchate

$\left(\mathrm{CIL} \mathrm{I}^{2}, 1211=\right.$ ILLRP 973). ${ }^{1}$

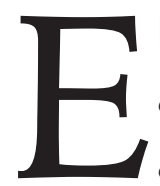

I epitafio fúnebre anteriormente descrito es considerado el elogio femenino más antiguo compuesto en verso en el mundo romano. A través de ocho frases se aglutinan las principales virtudes tanto conyugales, materiales, sociales, económicas y domésticas que debían tener las matronas romanas (FERNÁNDEZ MARTíNEZ, 2016, p. 19-20). Aunque hace alusión a una tal Claudia, siempre tendremos la duda de si se refería a una personal real o más bien a una idealización. El epígrafe nos anima a detenernos y conocer el curriculum uitae de la difunta. Fue una mujer bella que no hizo falta que tuviera un sepulcro ostentoso, sino que la sencillez de su sepultura fue reflejo de la vida que había llevado. Nos indica que fueron sus progenitores quienes impusieron su nombre. Llegando a la parte central del texto, se señalan dos funciones o responsabilidades que tuvo: amó a su marido con todo su corazón y le dio dos hijos. Uno de ellos le había sobrevivido, mientras que el otro había fallecido antes que ella. Se ensalzaban por tanto el matrimonio y la maternidad como facetas fundamentales (CENERINI, 2009, p. 17). La única cualidad que se alejaba de sus deberes conyugales y maternales era el tejido (lanifica). Sin embargo, esta actividad fue considerada como una de las tareas fundamentales de las matronas. De hecho, tal y como recuerda Pomeroy, el trabajo de la lana tanto en Grecia como en Roma fue algo exclusivamente femenino, hasta el punto de considerarse un estereotipo sexuado. En los enterramientos de las edades bárbaras era frecuente la presencia de un huso y constituía uno de los principales objetos para poder identificarlas en las necrópolis (POMEROY, 2004, p. 222).

En Claudia se aglutinaban cualidades propias de las mujeres de la nobilitas, las auténticas matronas. Artemidoro (II, 20) diferenció a las féminas bajo dos parámetros. Por un lado, estaban las cumplidoras del hogar, que eran las matronas; mientras que aquellas que se mostraban salvajes eran consideradas como prostitutas. Esta división fue

\footnotetext{
${ }^{1}$ En el original: "Hospes quod deico paullum est, asta ac pellege./ Heic est sepulcrum hau pulcrum pulcrai feminae./ Nomen parentes nominarunt Claudiam./ Suom mareitum corde deilexit souo./ Gnatos duos creauit: horunc alterum/ in terra linquit, alium sub terra locat./ Sermone lepido, tum autem incessu commodo./ Domum seruauit, lanam fecit. Dixi. Abei". Traducción obtenida de Fernández Martínez (2016, p. 19).
} 
defendida no solo por el autor de Éfeso, sino que imperó en el pensamiento patriarcal romano. Cuando los antiguos discutían sobre los roles sociales adscritos a las mujeres romanas, utilizaban la idea de la femina bona que destacaba por el trabajo de la lana, por su fidelidad, además de por una serie de cualidades contrapuestas a la meretrix o prostituta (CONESA NAVARRO, 2016, p. 207). Estos dos modelos femeninos antagónicos también se diferenciaron por la forma de vestir (STRONG, 2016, p. 18). La realidad de mujeres hermosas, adorables, fértiles, castas y especialmente buenas amas de casa, fueron cualidades expresadas no solo en el epitafio de Claudia, sino también en las diferentes lápidas repartidas por todo el territorio romano (KNAPP, 2011, p. 69).

Bajo esos parámetros se establecieron prototipos de mujeres virtuosas y perfectas, frente a otras que se caracterizaron por transgredir el espacio doméstico. Sin duda, las amazonas sería uno de los mitos más recurridos por los antiguos autores grecolatinos para contrarrestar la imagen de la íntegra mujer. Tal y como ha afirmado Molas Font (2013), las amazonas fueron un ejemplo ilustrativo de la construcción de la alteridad por parte de los griegos antiguos. La organización que presentaban las diferentes poleis griegas, caracterizadas por su complejidad y jerarquización social, no daban cabida a la participación política de ninguna mujer. No comprendían cómo había sociedades en las que el grado de intervención política no estaba regido por el nacimiento dentro de una determinada clase social o sexo, sino por la capacidad económica para disponer de armamento (MOLAS FONT, 2013, p. 551). Se ha cuestionado si estábamos ante un mito creado o si realmente existieron dichas mujeres. Los nuevos estudios arqueológicos, especialmente derivados del análisis del carbono catorce, están confirmando la autenticidad de guerreras contemporáneas a los griegos. Principalmente se conocen tumbas femeninas principescas con grandes ajuares en una zona amplia que comprendía desde el Mar Negro hasta parte del continente asiático (MAYOR, 2017, p. 49-71). Las amazonas además de ser doncellas violentas fueron presentadas en los poemas homéricos como seres "hostiles al hombre" $\mathrm{y}$ con cierto carácter varonil (Homero, llíada, IV, 189; IV, 186; IRIARTE GOÑI, 2002, p. 103).

Independientemente de que estemos en una sociedad patriarcal, las mujeres romanas no estuvieron aisladas en los gineceos como ocurrió con las griegas. Por el contrario, contamos con referencias, tanto literarias como epigráficas, que demuestran la intervención femenina en actividades de carácter religioso y político desde los primeros tiempos de la historia de Roma. El poder asociativo y el patronato de actividades culturales y edilicias pudieron ser llevadas a cabo por ciertas matronas con desahogada capacidad económica que se involucraron en actividades de carácter civil. ${ }^{2}$

${ }^{2}$ Sobre estos aspectos entre otros, cf. De La Rosa Cubo (2000, p. 53) y Hemelrijk (2015, p. 227). Sobre la fuerza ejercida 
Escribir sobre Lucrecia y Virginia, ambas con gran transcendencia política y social, puede parecer algo atrevido. Han sido numerosos los estudios que se han realizado. Sin embargo, en este trabajo pretendemos analizar sus historias desde la importancia que tuvieron para el resto de las mujeres y en especial como prototipos indispensables dentro de la educación femenina romana. Puede parecer de nuevo osado hablar de mujeres como colectivo, pues la realidad geográfica, social e incluso temporal, permitió que no existiera un patrón único. De igual forma, las referencias que tenemos procedían de aquellas pertenecientes a las clases sociales privilegiadas. Sin embargo, la prudencia además de poseer el honor familiar fueron características compartidas tanto por esclavas como por matronas. Por tanto, alejarse de dichas virtudes suponía para el pensamiento romano ser denostadas, sin pudicitia o pudor, máximas que explicaban la integridad sexual y el honor femenino (PERRY, 2004, p. 11). Estos valores se inculcaban desde la infancia tanto en el ámbito doméstico como en las escuelas. Al igual que los varones, que tenían personajes legendarios relacionados con la guerra y la política que eran sus modelos de conducta, las mujeres también tuvieron en Lucrecia y Virginia ejemplos de perfectas mujeres. Estos protagonistas míticos de Roma tuvieron un especial interés en el período arcaico. Debido al desconocimiento de la escritura, estas historias se transmitieron de manera oral dentro del sistema educativo familiar. Con el transcurso de los siglos las narraciones se fueron alterando y manipulando, añadiéndose experiencias sociales e imaginaciones religiosas. Estas historias de héroes nacionales contribuyeron de manera decisiva a formar la conciencia popular, cuya función didáctica, social e incluso ética, fue vital (FRASCA, 1991, p. 11-12). En Roma las mujeres en ocasiones protagonizaron algunos momentos cruciales de la Historia de Roma. Gracias a su intervención, algunas veces de manera dramática, con el pago de la propia vida, posibilitaron un cambio significativo en el orden establecido, lo que permitió que fueran vistas sus muertes como algo menos traumático (FRASCA, 1996, p. 64-65).

\section{Lucrecia: el suicido como honor familiar}

El episodio de Lucrecia es considerado como uno de los relatos angulares de la Historia primitiva de la urbs. La muerte de la esposa de Colatino suscitó gran atención, mucho más que otros acontecimientos de similares características para el devenir de Roma (BAUMAN, 1993, p. 550). Llegó a ser un referente no solo para la época clásica, sino

por las mujeres en época republicana cf. Cid López (2010, p. 125-151; 2015, p. 187-212; 2017, p. 207-231) y Martínez López (2017, p. 105-131). 
que se ha mantenido presente en la literatura universal, la pintura y el arte en general. Tito Livio está considerado como el autor que describió de manera más detallada el relato. En parte, su importancia va más allá del ideal de mujer casta, virtuosa, fiel y honesta que se pretendía transmitir con la mujer de Colatino (BAEZA ÂNGULO; BUONO, 2013a, p. 264; BAEZA ÂNGULO; BUONO, 2013b, p. 33). La importancia de sus actos radica en las consecuencias políticas que desencadenó su muerte. Una vez que se suicidó, en el 509 a.C., se instauró, según la tradición, la República, poniendo fin al gobierno tiránico de Tarquinio el Soberbio (FUENTES MORENO, 2009, p. 88; STEVENSON, 2011, p. 185-186).

En esta época tan arcaica el respecto a las costumbres de los antepasados y el honor familiar fueron vitales. Estamos ante un período en el que el derecho quiritario constituía la base fundamental de toda estructura. Desde los tiempos de Rómulo, el paterfamilias tenía pleno derecho sobre la vida o muerte tanto de sus hijos como de las personas dependientes de su domus. No se hacían distinciones entre sexos ni tampoco en función de la clase social (GARDNER, 1991, p. 6). Si bien es cierto que esta autoridad con el transcurso del tiempo se fue mitigando. Por ejemplo, a principios del siglo III d.C. un padre que mataba a sus descendientes tenía que rendir cuentas, a menos que hubiera actuado conforme a una decisión sancionada por un consilum familiar. Si bien es cierto que este poder fue aminorando ya en época imperial, siguió persistiendo cierto control sobre la vida y la muerte a partir del rito de la expositio que se mantuvo hasta bien entrado el cristianismo (DIXON, 1992, p. 46-47).

Todo acto que iba contra las antiguas costumbres gentilicias o leyes regias se sometió a juicio. En un principio, los principales delitos se dirimían dentro del consilium familiar, sistema que prácticamente quedó caduco ya en época imperial (DIXON, 1992, p. 117-118; PAVÓN, 2008, p. 685; CONESA NAVARRO, GONZÁLEZ FERNÁNDEZ, 2015, p. 9091). En el relato de Lucrecia se aunaron todas estas características y en cierta manera nos ayuda a entender cómo vivían los romanos de los períodos monárquico y altorepublicano. Por tanto, independientemente de la veracidad del relato, podemos afirmar que la importancia de la historia de Lucrecia se debía por dos aspectos fundamentales. Por un lado, muestra a la perfección los mecanismos y poderes que tenía el varón frente a la mujer, y, por el otro, las maniobras de sometimiento, así como la conciencia femenina que había del respeto a las costumbres y leyes antiguas. De igual forma, en el segundo ejemplo que trataremos, que fue el caso de Virginia, el paterfamilias aparecía como la máxima autoridad que llegó a matar a su propia hija. Puede parecer sorprendente que no se cuestionara la determinación que tuvo Virginio de asesinar a su hija, sino más bien la situación que lo había motivado para llegar a ese punto. 
La obra de Livio fue parte de la política de engrandecimiento de la figura del princeps. Bien es cierto, que conforme avanzó el gobierno de Augusto el escritor terminaría desilusionándose, quedando de manifiesto a partir de su pensamiento y creencia en el pasado republicano como el período más honorable del Imperio (MARCELO MARTINO, 2009, p. 52). Concretamente, los primeros libros de su Ab urbe condita, que son los que hacen referencia a los pasajes que vamos a comentar, tendríamos que situarlos en el período de la victoria de Octaviano sobre Marco Antonio y durante los primeros años del gobierno de Augusto (PHILIPS, 1982, p. 1029; JOSHEL, 2002, p. 165). Los personajes empleados son anacrónicos, no pudiéndose decir que estemos ante una obra científica o que los datos fueran tomados de escritores precedentes o archivos (STEVENSON, 2011, p.187). Es más, el propio autor en su introducción al libro primero advertía al lector de que era consciente que había pasajes de la Historia de Roma que quedaron obscurecidos con el paso del tiempo. Sin embargo, no se pudo resistir a narrar aquellos considerados gloriosos y que demostraban el espíritu romano en su plenitud (Liv., Ab urb. cond., I, 1-6). Situación también expresada por otros autores como Plutarco quien, con parámetros similares, señalaba las dificultades que entrañaba analizar los orígenes de Roma (Plutarco, Romulo, XIV, 2). Por tanto, creemos que culpabilizar a Livio de que sus datos no fueran veraces es algo injusto. Su intención no era crear una historia al uso, o por lo menos en sus primeros libros, sino mostrar la grandeza del pueblo romano a través de una serie de leyendas que daban identidad a la civilización romana. Estamos de acuerdo con Stevenson cuando afirmó que su afán era reflejar una serie de exempla morales muchas veces contrapuestos. Situaciones y formas de vida que había que intentar evitar o, todo lo contrario, imitar (STEVENSON, 2011, p. 187). En una sociedad patriarcal como la romana no era extraño que los valores femeninos más importantes fueran aquellos relacionados con el silencio, acatar la decisión masculina y el respeto a los mores maiorum. De hecho, como bien explicó Joshel, teniendo en cuenta los antecedentes anteriormente expuestos, el historiador podía haber obviado o abreviado diferentes aspectos, o por lo menos podría haber minimizado el papel atribuido a las mujeres en su relato. Sin embargo, describió los acontecimientos con gran detalle y empleó una amplia panoplia de técnicas y recursos literarios que en cierta manera aumentaban el dramatismo de los hechos transmitidos (JOSHEL, 2002, p. 169).

Para poder situarnos en el relato de Lucrecia, nos tendríamos que retrotraer al año 509 a.C. durante el fulgor del asedio de Ardea. Una noche en la que los combatientes estaban bebiendo, se disputaron cuál de ellos tenía la mejor esposa. Fue entonces cuando el propio Tarquinio Colatino sentenció que su esposa Lucrecia superaba a las del resto. Decidieron que, para salir de dudas, lo mejor sería ir al encuentro de sus mujeres sin previo 
aviso y así ver cuál de ellas era la que gozaban de mayores cualidades (Liv., Ab urb. cond., I, 57, 6-8; Ovídio, Fastos, II, 731-738). Parece que las nueras del rey fueron sorprendidas en un suntuoso banquete, mientras que, por el contrario, Lucrecia se encontraba junto con sus esclavas tejiendo la lana. Esta actitud irreprochable, junto con su belleza natural, fueron los desencadenantes para que Sexto Tarquinio sintiera un deseo incontrolable por poseerla (Liv., Ab urb. cond., I, 57, 8-11). Por el contrario, Dionisio de Halicarnaso nos ofrece una versión distinta. El primer encuentro entre Lucrecia y el hijo del rey no fue a consecuencia de una apuesta, sino que viajó a Colacia por mandato de su padre, Tarquinio el Soberbio, y fue entonces cuando al verla se enamoró perdidamente de la joven doncella (Dion. Hal. Ant. Rom. IV, 64, 2-5). ${ }^{3}$

Unos días después, Sexto regresaría a la casa de Tarquinio Colatino pues no había cesado su deseo. La fecha estimada fue del 22 al 23 de febrero (FRASCA, 1991, p. 209). En esta ocasión Lucrecia estaba sola sin la protección de sus familiares, por lo que a consecuencia de su vulnerabilidad hizo que el hijo de rey tuviera la ocasión perfecta para declararle sus sentimientos. Como en la situación anterior, Lucrecia recibió al invitado con agrado. Una vez que estaban todos dormidos y que por lo tanto no levantaba sospechas, se dirigió a los aposentos de la doncella con una espada para intimidarla, la asaltó y le dijo: "Silencio, Lucrecia; soy sexto Tarquinio, estoy empuñando la espada; si das una voz te mato" (Liv., Ab urb. cond., I, 58, 2-3). ${ }^{4}$ Livio nos muestra a un Sexto Tarquinio enloquecido, no solo por su atrevimiento al ir a los aposentos de una matrona respetable y casada, sino por la forma en la que la abordó. La mujer de Tarquinio Colatino despertó despavorida. Sexto a la misma vez que le imploraba y suplicaba que accediera a sus pretensiones, intentando mostrarle su amor y prometiéndole hacerla reina, la amenazaba (Liv., Ab urb. cond., I, 58, 3-4). ${ }^{5}$ Viendo que su espíritu era fuerte y que no se doblegaba, tomó la determinación de amenazarla de muerte. Además de su cadáver, también haría lo propio con un esclavo y así justificaría que ambos fueron asesinados por cometer flagrante adulterio (Liv., Ab urb. cond., I, 58, 4-5). ${ }^{6}$ Sin embargo, en este aspecto encontramos una contradicción con las normas que imperaban en Roma desde la época de Rómulo (Dion. Hal. Ant. Rom. II, 25, 6-7). ${ }^{7}$ Efectivamente, el adulterio era una de las causas por las que una mujer podía ser

\footnotetext{
${ }^{3}$ Diodoro de Sicilia parece que coincidió con la versión de Dionisio de Halicarnaso, ya alude que Sexto fue a Colacia y no menciona que fuera el resto de los combatientes ni tampoco alude a ninguna apuesta. Cf. Diod. Sic. (X, 20, 1).

${ }^{4}$ Concretamente, las palabras de Lucrecia fueron las siguientes: "Tace, Lucretia" inquit; "Sex. Tarquinius sum; ferrum in manu est; moriré si emiseris vocem" (Liv., Ab urb. cond., I, 58, 3). Este mismo pasaje, con similares características fue reproducido por Dion. Hal. (Ant. Rom., IV, 64, 5; 65, 1-4).

${ }^{5}$ Esa misma idea es reproducida en Dio. Sic. $(X, 20,2-3)$.

${ }^{6}$ Esa misma sucesión de hechos es reproducida por Diodoro de Sicilia (Cf. Dio. Sic., X, 20, 1-2; DONALDSON, 1982, p. 4). ${ }^{7}$ Dionisio de Halicarnaso menciona que para los romanos la ingesta de vino y el adulterio fueron los delitos femeninos más significativos, en los que la mujer podía ser castigada con la muerte misma.
} 
asesinada. Se ha discutido si realmente dicha ley fue instituida por Numa y no por el primer rey de la urbs. En las leges regiae se establecía que un marido podía matar a su esposa en caso de encontrarla practicando sexo con otro varón. De igual forma, los parientes también podían ejercer ese derecho, especialmente los más directos (CANTARELLA, 1991, p. 121-122). Sin embargo, en principio, a Sexto Tarquinio no le correspondía sentenciar el supuesto delito. Bien es cierto que podría haber justificado su acción argumentando que era pariente de Colatino. Sin embargo, previamente tendrían que haber sido juzgada la doncella por un tribunal familiar, el iudicium domesticum. Por tanto, estamos de acuerdo con Bravo Bosch de que nos encontramos ante una irregularidad en el proceso jurídico de haberse producido la amenaza del hijo de Tarquinio el Soberbio. De todas formas, no queda del todo claro las competencias de este primitivo consejo familiar si eran de carácter penal o judicial (BRAVO BOSCH, 2013, p. 25; BRAVO BOSCH, 2017a, p. 83).

Solo las amenazas de la pérdida de la honra familiar fue lo que permitió que finalmente accediera a las pretensiones de Sexto. Más allá del dolor físico, el daño moral estaba por encima de cualquier otra cuestión. El honor de la familia dependía en gran parte de la capacidad del paterfamilias para proteger su hogar. Además, todos sus miembros contribuían en la virtud y prestigio de su casa (SALLER, 1984, p. 353). Por tanto, Lucrecia no tenía otra escapatoria. Era consciente que pese a ser inocente, había sido mancillada y ese stuprum se transmitiría a las futuras generaciones (BRAVO BOSCH, 2013, p. 20). Sin esperanzas y abatida por lo sucedido, hace llamar a su padre y a su marido que se encontraban fuera de Colacia. Una vez llegados a la ciudad y en presencia del concilium necessarium, como definió Valerio Máximo $(6,1,1)$, se dispuso a explicar lo sucedido antes de clavarse un puñal en el corazón ${ }^{8}$ con el que ponía fin a su vida (BRAVO BOSCH, 2013, p. 20-21; BRAVO BOSCH, 2017a, p. 140-141). La referencia al tribunal familiar ha traído controversias debido a que, si seguimos el testimonio de Livio, fue ella la que lo convocó. Lucrecia, al carecer de patria potestad no tendría autoridad de convocatoria, pues estaba reservada únicamente al paterfamilias (BRAVO BOSCH, 2017a, p. 141-142). Sin embargo, en el relato de Dionisio de Halicarnaso (Ant. Rom. IV, 67, 1-2) fue la propia doncella la que salió al encuentro de su padre al día siguiente de los hechos. Ataviada para la ocasión, vestida de negro y con el arma escondida, fue hasta Roma y en presencia de

\footnotetext{
${ }^{8}$ Liv. (Ab urb. cond., I, 58, 11-12), Ov. (Fast. II, 782-836) y Dion. Hal. (Ant. Rom. IV, 67, 1-2). Concretamente, las palabras pronunciadas por Lucrecia y reproducidas por Livio fueron las siguientes: "Vosotros veréis- responde- cuál es su merecido, por mi parte, aunque me absuelvo de culpa, no me eximo de castigo; en adelante ninguna mujer deshonrada tomará a Lucrecia como ejemplo para seguir con vida" (Liv., Ab urb. cond., I, 58, 11, trad. J. A. Villar Vidal, 1990)". Por su parte, Diodoro de Sicilia no menciona el alegato de Lucrecia, aunque la sucesión de los acontecimientos no varía (Cf. Dio. Sic. X, 20, 3).
} 
su paterfamilias y de unos familiares cayó a sus pies llorando. Las palabras pronunciadas por ella fueron las siguientes:

Padre - dijo - vengo a ti como suplicante, pues he sido víctima de un ultraje terrible e irreparable, para pedirte que me vengues y que no mires con indiferencia que tu hija haya sufrido algo peor que la muerte (Dion. Hal., Ant. Rom., IV, 66, 2-3).9

El padre angustiado preguntó quién la había ultrajado y a que delito en concreto se refería, por lo que prosiguió la virtuosa matrona diciendo:

Pronto oirás mis desventuras, padre - dijo -, pero primero concédeme este favor que te pido: llama a cuantos amigos y parientes te sea posible para que escuchen de mí, que soy la que lo ha sufrido y no de otros, el terrible suceso. Cuando conozcas la vergonzosa y terrible violencia a que me he visto sometida, decide con ellos de qué modo vas a vengarnos a ti y a mí; y no dejes pasar mucho tempo (Dion. Hal., Ant. Rom., IV, 66, 3). ${ }^{10}$

Una vez más la joven exigía que su muerte no quedara impune y que no se dilatara mucho en el tiempo la venganza que le encargaba a sus familiares. Más interesante fue el tema del consilum domesticum. Tal y como hemos visto en el testimonio de Tito Livio, se presuponía que la joven no se desplazó de su domus, sino que esperó a sus familiares y en presencia de ellos tomó la determinación de suicidarse. Este pasaje ha traído consigo discrepancias entre la comunidad científica. Sin embargo, en el relato de Dionisio de Halicarnaso fue la propia Lucrecia la que se desplazó a Roma y no fue ella quien convocó al consejo familiar. Interesante resulta la última frase de los fragmentos presentados, pues en ella se observa como Lucrecia era consciente que la violación sufrida no solo suponía un agravio para ella, sino para su padre y por ende para toda la estirpe.

Pese a que se considera el texto de Livio como el principal testimonio para reconstruir la historia de Lucrecia, pensamos que las inconexiones y errores que contiene en lo que se refiere a la convocatoria del consejo familiar, hace que creamos más lógico el planteamiento ofrecido por Dionisio de Halicarnaso. Sigue exponiendo el autor griego que una vez reunidos todos los hombres que componían el consilium y tras relatar la

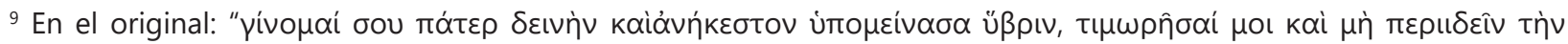

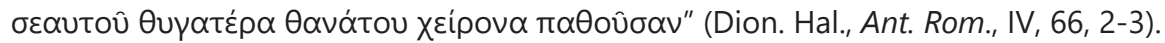

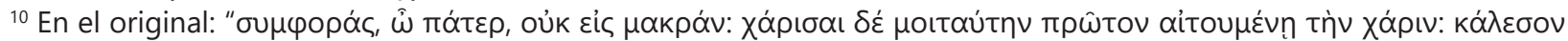

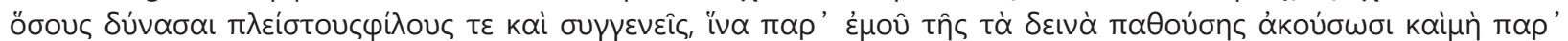

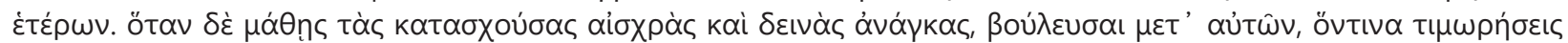

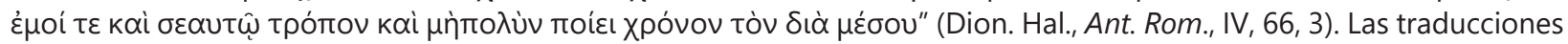
del texto de Dionisio de Halicarnaso son de los Clásicos Gredos. Concretamente, las traducciones fueron las de A. Alonso y C. Seco (1984).
} 
violación, la virtuosa matrona sacó una daga que llevaba escondida entre sus ropas y se la clavó en el corazón. Su muerte conmocionó a los presentes y en especial a las mujeres, formándose un gran griterío (Dion. Hal., Ant. Rom., IV, 66, 1-2). ${ }^{11}$ La entereza que mostró la joven despertó simpatías y halagos por parte de los autores clásicos. Sin duda, uno de los calificativos más sorprendentes fue el realizado por Ovidio (Fast., II, 847-848), quien la consideró como una matrona de espíritu varonil (animi matrona uiriles), cuya muerte trajo consigo muchas lágrimas.

El hecho de que Lucrecia empleara para suicidarse un cuchillo o una daga también tiene su valor tal y como ha indicado Bravo Bosch, pues fue una demostración de su prestigio social. El ahorcamiento se consideraba infame. Lo mismo hubiera sido el arrojarse desde una altura, que además habría traído consigo la confiscación de sus bienes. Lo más idóneo habría sido el empleo de una espada, pero debido al peso de ésta y a su inexperiencia en su manejo, finalmente optaría por un arma blanca de menores dimensiones (BRAVO BOSCH, 2017a, p. 108-109). Otra posibilidad, aunque por supuesto son meras conjeturas, sería que, de utilizar una espada habría sido mucho más difícil esconderla. Todas las referencias sin excepción hablan de que tenía oculta el arma entre las vestiduras. Por tanto, difícil habría sido encajar el relato si hubiera llevado una espada ante un espacio repleto de familiares sin levantar sospechas. En época imperial tenemos el ejemplo de Arria, ${ }^{12}$ que también se suicidó con un puñal y cuya valentía fue ensalzada por los autores clásicos. ${ }^{13}$ Su determinación encomiable fue conocida por todo el territorio romano y fue ejemplo de imitación (MOSQUERA SOUTO, 2000, p. 253).

El encargado de extraer el arma del cuerpo de Lucrecia fue Bruto, quien lideraría la posterior expulsión contra Sexto Tarquinio y toda la monarquía. Como observamos, al igual que sucedió con Lucrecia, cuya culpa afectaba a toda su estirpe, lo mismo ocurrió con Sexto, cuyo acto vil supuso la eliminación de los reyes en Roma. Las descripciones ofrecidas tanto por Livio como por Ovidio prácticamente se limitaron a indicar que Bruto prometió llevar a cabo la venganza (Liv., Ab urb. cond., I, 59, 1-2; Ov., Fast., II, 837-846). Más descriptiva fue la versión ofrecida por Dionisio de Halicarnaso. Con respecto a las otras lecturas hay ciertas variaciones. En el relato del autor griego no se encontraba el

\footnotetext{
${ }^{11}$ Otras versiones son las siguientes: Liv. (Ab urb. cond., I, 58, 11-12) y Ov. (Fast., II, 782-836).

${ }^{12}$ Sobre la historia de Arria nos tendríamos que remontar a la época del emperador Claudio. Ésta fue esposa del cónsul sufecto del año 37 d.C. Cecinia Peto. Debido a la supuesta participación del cónsul en una rebelión contra el propio emperador, la pena fue el suicidio. Una vez que fueron apresados, quien tomó la determinación de acabar con sus vidas fue la propia mujer. Cogió un puñal, se lo clavó e instó a su marido para que hiciera lo mismo diciéndole que no dolía: "Petus, non dolet" (Plinio, Epistulae, 3, 16, 6). Otros autores clásicos nos ofrecen ciertas variaciones de esta historia (Martialis, 1, 13; D.C., 60, 6-7). Sobre este pasaje, cf. Conesa Navarro; González Fernández, 2016, p. 604-605.

${ }^{13}$ Entre ellos destacan los calificativos de Plinio que lo consideró como un acto glorioso que llevó consigo no solo su imitación, sino la inmortalidad de esta mujer (Cf. Plin., Epist. 3, 16, 6).
} 
marido de Lucrecia en el lugar donde ésta cometido suicidio. Fue a través de un emisario, Publio Valerio, quien fue al campamento donde se encontraba Tarquinio Colatino y le contó lo sucedido (Dion. Hal., Ant. Rom., IV, 67, 3). Cuando llegó a su casa y halló el cuerpo sin vida de su esposa junto con su padre, Tarquinio corrió hacia ella y la besó como si todavía estuviera viva. Los lamentos de familiares fueron abundantes (Dion. Hal., Ant. Rom., IV, 70, 2-3). Fue a partir de entonces, cuando vemos que Bruto adquirió cierto protagonismo en el relato y no solo eso, sino que animó a tomar las armas y vengar la muerte de la joven (JOSHEL, 2002, p. 172). ${ }^{14}$ Fue el encargado de poner cierta cordura, pues sentenció advirtiendo que ya tendrían tiempo para llorar la triste pérdida. Lo que apremiaba era honrar su memoria expulsando a los malhechores (Dion. Hal., Ant. Rom., IV, 70, 3-4). De hecho, Dionisio de Halicarnaso continúa el relato mencionando que Bruto alentó al padre, marido y a todos los varones presentes para que de manera unánime se movilizaran para expulsar al rey Tarquinio el Soberbio y a toda su familia (Dion. Hal., Ant. Rom., IV, 70, 4-5). Tras pronunciar dicho alegato, extrajo el arma con el que la joven se había suicidado y juró ante los dioses sus intenciones (Dion. Hal., Ant. Rom., IV, 70, 5). ${ }^{15}$ Tras ello, el resto de los asistentes con la daga prestaron el mismo juramento y Bruto, como líder, planeó la estrategia a seguir (Dion. Hal., Ant. Rom., IV, 71, 1-6). Plutarco en la vida de Publícola $(1,3)$ referenciaba que, la muerte de Lucrecia realmente fue un pretexto para eliminar la monarquía. El pueblo estaba cansado de la manera tiránica con la que gobernaba Tarquinio el Soberbio, pues había ocasionado demasiado odio en la población. Algo similar señalaba Eutropio, quien dijo que, Tarquinio el Soberbio perdió el poder a consecuencia de que su hijo violó a Lucrecia, considerada la más noble y virtuosa mujer. Una vez que se quitó la vida, Bruto, pariente del rey, instigó al pueblo para eliminar la monarquía (Eut., Breviarium historiae Romanae, 1, 8, 2-3).

Livio describe a Lucrecia como uno de los principales prototipos de matrona romana. En ella iba adherida la castidad y la prudencia que llevó hasta el extremo. Según Donalson el trasfondo de dicha muerte fue mayor, pues Lucrecia podría responder más bien a una alegoría de la propia Roma. Es decir, a través de la personificación, se pretendía demostrar que la monarquía era un sistema caduco, pues estaba constantemente violando los principios sociales (DONALDSON, 1982, p. 9). De las tres versiones ofrecidas, Livio, Ovidio y Dionisio de Halicarnaso observamos que hay diferencias considerables

\footnotetext{
${ }^{14}$ Cicerón, en su República, habla de que Bruto fue el ejemplo de ciudadano que adquirió notoriedad por liberar a los ciudadanos de la esclavitud que ejercieron los reyes. Previamente presentó al personaje de Lucrecia, diciendo que fue una mujer casta y noble, que se castigó a su misma por un ultraje recibido (Cic., De Republica, II, 46). Alusión que también hace a la doncella en su libro sobre las Leyes (Cicerón, De Legibus, II, 10).

${ }^{15}$ Sobre el hecho de que Bruto extrajera el arma del cuerpo sin vida de Lucrecia y su posterior venganza, también fue descrito por otros autores, aunque de manera más breve (Cf. Liv. Ab urb. cond., I, 59, 1-2; Ov., Fast., II, 837-846).
} 
en la narración entre los dos primeros y el último. Para el historiador griego no había un concurso entre las diferentes esposas de los combatientes de Árdea, sino que Sexto Tarquinio vio a Lucrecia por primera vez cuando el rey lo envió. Otra vez de nuevo, al final del relato se produce una discordancia entre los tres clásicos. A través de la versión ofrecida por Dionisio de Halicarnaso, hemos visto que fue la propia Lucrecia la que se desplazó a Roma para contarle a su padre todo lo sucedido, pero más significativo fue que, el marido de la matrona no se encontraba en el mismo lugar en el que ella se suicidó. Todas estas inconexiones hacen pensar que, en un primer momento, lo que se pretendía destacar de Lucrecia era su carácter casto, honrado y fiel. Con el paso del tiempo, el ideal y estereotipo adquirido se fue ampliando (ÁLVAREZ; IGLESIAS, 1998, p. 53). ${ }^{16}$ De hecho, en el pasaje de Diodoro de Sicilia más que el relato en sí habría que destacar la valoración que realizó de ella tras suicidarse. ${ }^{17}$ Nos dice que, no habría que denostar este acontecimiento, pues constituía un ejemplo para futuras generaciones. Las mujeres que preferían mantener su pureza, pese a la dureza de las consecuencias, encontrarían un claro ejemplo en ella. Muchas, por el contrario, ante casos similares a los sufridos por la mujer de Colatino, lo guardaban en silencio mientras que Lucrecia no solo lo hizo público, sino que fijó la pena de su agravio. Por tanto, obtuvo una gloria inmortal a partir de una vida mortal (Diodoro Siculo, Bibliotecae Historicae, X, 21, 1-5). Con esta preciosa frase terminaba de ensalzar su figura y podríamos decir que en ella se sintetizaba su principal cualidad: su inmortalidad a través de sus hechos. Los objetivos que se propuso Lucrecia se cumplieron con creces, ya que pese a ser cuestionada y criticada por escritores de la época cristiana ${ }^{18}$, su fama y su vida perduró hasta nuestros días, siendo su violación y suicidio reproducido por numerosos pintores, escritores y artistas de todas las épocas.

\section{Virginia, exemplum de muerte justificada}

Virginia fue la Lucrecia de la plebe. Mientras que la primera podríamos considerarla como un sujeto de carácter activo al ser ella quien tomó la iniciativa de poner fin a su vida, la hija de Virginio fue todo lo contrario, fue asesinada y no conocemos ningún discurso o palabra suya acerca de su trágico final. No hay duda de que, al margen de los problemas interpretativos, Lucrecia tomó una decisión sin ser presionada. Fue ella quien con plenas

\footnotetext{
${ }^{16}$ Diodoro de Sicilia $(X, 20,1)$ comparte con el resto de los autores la definición de Lucrecia como una mujer de gran belleza y de virtuoso carácter.

17 De manera resumida, Diodoro de Sicilia parece que siguió la versión ofrecida por Tito Livio.

${ }^{18}$ Agustín de Hipona (De Ciuitate Dei, I, 19) fue especialmente crítico. El suicidio en el pensamiento cristiano era un acto cobarde, pues solo Dios tenía potestad para arrebatar la vida a una persona (Cf. FUENTES MORENO, 2009, p. 107; GALLEGO FRANCO, 2015, p. 320; CONESA NAVARRO; GONZÁLEZ FERNÁNDEZ, 2016, p. 595-605).
} 
facultades se suicidó. Por el contrario, el deceso de Virginia fue la consecuencia directa de las normas marcadas por los mores maiorum. Cuando la situación era insostenible y no se albergaba otra salida ante una situación de tal calibre era preferible el suicidio. ${ }^{19}$ Pese a las diferencias, ambas se caracterizaron por su integridad, desencadenando transformaciones en acontecimientos políticos y sociales de gran entidad. Las comparaciones entre las doncellas fueron ya puestas de manifiesto por Tito Livio en su obra. Cuando presentó a la hija de Virginio nos anunciaba que estábamos de nuevo ante un crimen pasional al igual que había ocurrido con la esposa de Colatino (Liv., Ab urb. cond., III, 44, 1). Ambas tuvieron la particularidad, como se ha anunciado, de tener consecuencias importantes para la Historia de Roma. Mientras que la primera había traído consigo la eliminación de la monarquía en Roma, la segunda supuso el final del decenvirato (KRAUS, 2010, p. 413). Diodorio de Sicilia menciona que, como Lisanias llegó a ser arconte de Atenas en el siglo $\checkmark$ a.C., los romanos también tuvieron a diez hombres encargados de codificar leyes, sin embargo, no llegaron a cumplir su objetivo por la actitud emprendida por uno de ellos, Apio Claudio (Dio. Sic., Bibl. Hist., XII, 24, 1-2).

Virginia era hija del ilustre Lucio Virginio, definido por Tito Livio como un uir exempli recti domi mitiaeque (Liv., Ab urb. Cond., III, 44, 2). Esa ejemplaridad indicaba el alto respeto que profesaba hacia las costumbres y leyes romanas. Por tanto, podemos intuir que su grado de amor hacia la patria estaba por encima de cualquier acto por muy desagradable y doloroso que pudiera parecer. Para contextualizar el acontecimiento, tenemos que retrotraernos de nuevo al siglo $V$ a.C., concretamente al año 449 a.C. Apio Claudio, uno de los decenviros, se enamoró de la plebeya Virginia. Dionisio de Halicarnaso presenta a la joven como una de las mujeres más hermosas que había en Roma. Tenía la edad suficiente para ser casadera y estaba prometida con Lucio Icilio. Apio se enamoró cada vez más de la joven, pues la escuela se encontraba cerca del foro $y$, por lo tanto, estaba obligado a pasar cerca de donde ella se encontraba estudiando todos los días (Dion. Hal., Ant. Rom., XI, 28, 2-4). ${ }^{20}$ Pese a los deseos que tenía Apio de poseerla, no se podía casar con ella. Además de que estaba prometida a otro hombre, él tenía una esposa legítima. En tercer lugar, él era patricio y Virginia, sin embargo, pertenecía a una familia plebeya (Dion. Hal., Ant. Rom., XI, 38, 4). Sobre esto último hay que decir que Diodoro de Sicilia (Bibl. Hist., XII, 24, 2-5) fue el único autor que apuntó que la hija de Virginio tenía

\footnotetext{
${ }^{19}$ Así nos lo expresa Eutropio que dice que el padre la mató para que no tuviera que soportar una violación (Eutr., Breviarium Historiae Romanae, 1, 18, 1-2).

${ }^{20}$ Por su parte, Livio se limitó a mencionar que se apoderó de Apio Claudio un violento deseo de hacer suya a la joven (Liv., Ab urb. Cond., III, 44, 2).
} 
origen noble. Sin embargo, los autores que siguen la tradición analística señalaron todo lo contrario (FRASCA, 1991, p. 211).

Virginia era sponsa de Lucio Icilio. Los esponsales en Roma era el compromiso previo a la celebración del matrimonio. Consistían en una promesa de carácter jurídico a través de la formulación de una pregunta realizada de forma solemne entre los contrayentes, el futuro marido (el sponsus, el que promete) y la mujer (sponsa, la que promete). ${ }^{21}$ Estas proposiciones se realizaban a través de una serie de estipulaciones mutuas o esponsiones, de ahí el nombre, derivado del verbo latino spondere (prometer) ${ }^{22}$. Los datos referidos a la etapa preclásica son problemáticos e inciertos, originados por las escasas referencias literarias. Lo único de lo que se tiene cierta seguridad era que los contrayentes tenían que respetar el compromiso adquirido (ABAD ARENAS, 2014, p. 6). Por el contrario, en la época clásica no hacía falta ningún acto, en los períodos más arcaicos sí que había una celebración conocida como actio ex sponsu (MUÑOZ CATALÁN, 2011-2014, p. 355).

La cuestión de la esposa legítima es algo que no merece matización, pues en Roma no se contemplaba la poligamia. Sí que merece nuestra atención la prohibición del matrimonio entre patricios y plebeyos. Cuestión que imposibilitaba el enlace entre el decenviro y la hija de Virginio. Desde la codificación de las Leyes de las XII Tablas se prohibía taxativamente la unión entre patricios y plebeyos. Concretamente nos estaríamos refiriendo a la tabla número $\mathrm{XI}$, situación caduca e injusta ya criticada por Cicerón (De Rep., 2, 37, 63). Esta proscripción entre matrimonios mixtos fue eliminada mediante la promulgación en el año 445 a.C. de la lex Canuleia (HERREROS GONZÁLEZ; SANTAPAU PASTOR, 2005, p. 92). Todos estos requerimientos hacían que las pretensiones de Casio no se pudieran llevar a cabo, pues, aunque Virginia estuviera libre y no se encontrara prometida, su condición de plebeya imposibilitaba la unión. Virginio había tenido la suerte de conservar a su hija virgen y la había prometido a Lucio Icilio (Eut., Brev. Hist. Rom., 1, 18, 2).

Apio Claudio sabiendo que el espíritu de Virginio era inquebrantable, intentó seducir a la hija de éste a través de regalos y promesas, como también hizo Tarquinio con Lucrecia (Liv., Ab urb. Cond., III, 44, 4). Dionisio de Halicarnaso fue más explícito que Livio, indicando que debido a que era huérfana de madre, le ofreció importantes sumas de dinero y presentes. Envió a diferentes mujeres para que sobornaran a sus nodrizas con el propósito de no revelar la identidad del enamorado (Dion. Hal., Ant. Rom., XI, 28,

\footnotetext{
${ }^{21}$ Flor. (Dig. XIII, 1, 1): "Los esponsales son mención y promesa de futuras nupcias" (Sponsalia sunt mentio et repomissio nuptiarum futurarum). Trad. I. L. García del Corral (1892).

22 Ulp. (Dig. XIII, 1, 2): "Pero dijéronse esponsales de spondere (prometer) porque fue costumbre de los antiguos estipular y prometer para sí sus futuras mujeres" (Sponsalia autem dicta sunt a spondendo, nam moris fuit veteribus stipulari et sondere sibi uxores futuras). Tradução de I. L. García del Corral (1892).
} 
4-5). El caso omiso de Virginia hacia las ofertas del decenviro fue el detonante para que Apio Claudio actuara de manera diferente. Contrató a Marco Claudio para que tomara a la joven por la fuerza si era necesario. Le indicó que la reclamase como esclava suya y que se mostrara impasible ante las demandas de libertad provisional (Liv., Ab urb. Cond., III, 44, 4-5; Dion. Hal., Ant. Rom., XI, 28, 5-6). ${ }^{23}$ En un momento dado en el que Virginia se encontraba en el foro, pues se dirigía a las escuelas, aprovechó el cliente del decenviro la ocasión para llevar a cabo su cometido (Liv., Ab urb. Cond., III, 44, 6).

Dionisio de Halicarnaso informó que el lugar donde Maco Claudio apresó a Virginia fue en las escuelas (Dion. Hal., Ant. Rom., 28, 5-6). Sobre los centros de enseñanza en Roma a partir de los testimonios literarios hay una disparidad de cronologías. Según Tito Livio había centros de enseñanzas en los bajos del foro en ciudades como Tusculum durante el siglo IV a.C. (Liv., Ab urb. Cond., VI, 25, 9). Valerio Máximo retrotrae la fecha al siglo VII a.C. (Val. Max., Factorum et dictorum memorabilium libri novem, II, 1, 4). Sin embargo, parece que anterior al siglo III a.C. la educación romana se encontraba estrictamente reducida al contexto familiar. No sería hasta la intervención del liberto Espurio Carvilio Máximo Ruga, cónsul del año 234 a.C. y nuevamente en 228 a.C., cuando podamos situar la primera escuela en Roma con cierta seguridad (Dion. Hal., Ant. Rom., II, 25, 7; Aulo Gelio, Noctes Atticae, IV, 3; XVII, 21, 44; BONNER, 1984, 56; LEÓN LÁZARO, 2013, p. 473). Por tanto, si aceptamos dicha información encontraríamos un anacronismo, pues en esa época tan temprana Virginia no habría ido a una escuela, sino que su formación habría sido en un ambiente doméstico. Ya fuera en el foro o en la escuela, cuando Marco Claudio retuvo a la joven tuvo que ser en un lugar concurrido de gente, pues nos informan las fuentes que se formó un gran alboroto (Liv., Ab urb. cond., III, 44, 6-7; Dion. Hal., Ant. Rom., XI, 28, 6).

Livio explica que, precisamente, el enviado justificó que Virginia había sido hija de una esclava suya, por lo que tenía plena potestad para llevársela. Sin embargo, el ajetreo que se formó en el foro fue de tal envergadura que se vio imposibilitado. Apio Claudio decidió actuar en ese momento debido a que su padre no se encontraba en la ciudad (Liv., Ab urb. cond., III, 44, 5-7). ${ }^{24}$ Marco, ante un tribunal presidido por el propio Apio Claudio, argumentó que la muchacha en origen había nacido en su casa y que posteriormente fue raptada y presentada en la casa de Virginio, el que terminaría reconociéndola como hija suya. Según el demandante había pruebas suficientes para demostrar su alegato de las

\footnotetext{
${ }^{23}$ En el relato ofrecido por Diodoro de Sicilia se aúnan aspectos de las dos versiones anteriores, pero de manera sintética. Nos dice que Apio sintió un gran amor por la joven, intentó seducirla mediante regalos y dinero y viendo que no doblegaba, decidió enviar a un mensajero a su casa para tomarla como su esclava (Dio. Sic., XII, 24, 2-3). De igual forma nos dice que fue enviado éste a la casa de Virginia, no que fuera sorprendida en la calle.

${ }^{24}$ Diodoro de Sicilia, además de mencionar que fue apresada en la casa, nos indica que Virginio sí que se encontraba cuando ocurrió todo (Dio. Sic., Bibl. Hist., XII, 24, 4).
} 
que ni tan siquiera el propio Virginio podía negarse. Finalizaba su alegato reclamando que como realmente era una esclava debía continuar bajo la sumisión de su dueño (Liv., $A b$ urb. cond., III, 44, 8-11). ${ }^{25}$ Durante el pleito había congregados partidarios de Virginio que instaban a que se avisara al que hasta la fecha era considerado como el padre legítimo de la joven. No era justo cuestionar la paternidad de alguien que se encontraba ausente, por lo que pidieron que se aplazara la sesión (Liv., Ab urb. cond., III, 44, 12). Ante la ausencia de Virginio se presentaron Icilio, su prometido, junto con Publio Numitorio ${ }^{26}$. Uno de ellos intervino para defender los intereses de Virginia. Mientras que Livio reprodujo el discurso del prometido de la joven (Liv., Ab urb. cond., III, 45, 6-11), el otro autor mencionó que fue Numitorio quien interpeló por Virginia, acusando directamente a Apio Claudio de la situación que se estaba produciendo (Dion. Hal. Ant. Rom. XI, 30, 1-7). El decenviro sentenció que hasta que no viniera Virginio la joven debía permanecer en casa de Marco Claudio (Liv., Ab urb. cond., III, 45, 1-3; Dion. Hal., Ant. Rom., XI, 31, 1-5).

Esta decisión provisional provocó una gran conmoción (Dion. Hal., Ant. Rom., XI, $32,1-4)$. Una vez estando Virginio en la ciudad y vestido de luto, llegó con Virginia y unas matronas al foro. Tras los diversos alegatos y observando que no conseguía aplacar las pretensiones de Apio Claudio, decidió llevar a su hija a un lugar apartado, en las cercanías del templo de Cloacia. Cogió un cuchillo de carnicero y le indicó a su hija que la única libertar que le podía ofrecer era la muerte. Tras pronunciar dichas palabras atravesó el pecho de la joven con el arma (Liv., Ab urb. cond., III, 47, 1-2; 48, 5). ${ }^{27}$ Dionisio de Halicarnaso nos dice que, a Virginio le vino a la mente una acción dolorosa y a la misma vez amarga, pero debido a su condición de hombre libre y magnánimo, tras pedir permiso para dar los últimos abrazos a su hija y hablar a solas con ella, fue sacada del foro donde finalmente terminaría matándola con un cuchillo (Dion. Hal., Ant. Rom., XI, 37, 4-6). Tanto en Tito Livio como en Dionisio de Halicarnaso se reprodujeron las palabras que supuestamente pronunció Virginio a su hija. Pese a las variaciones existentes entre ambos autores, la idea transmitida fue la misma: la muerte estaba justificada, pues era la única salida remediable para solucionar una situación tan atroz. ${ }^{28}$ Tras asesinarla Virginio

\footnotetext{
${ }^{25}$ Con parámetros parecidos también se reproduce en la obra de Dionisio de Halicarnaso, entre las variaciones más destacadas que presenta el autor griego, podríamos decir que explica que fue la esposa de Virginio quien entabló negociaciones con una de las esclavas de la casa de Marco Claudio (Dion. Hal., Ant. Rom., XI, 29, 1-4).

${ }^{26}$ En Tito Livio, Publio Numitorio era su abuelo (Liv., Ab urb. cond., III, 45, 4), mientras que en la obra de Dionisio de Halicarnaso era su tío materno (Dion. Hal., Ant. Rom. XI, 28, 7). Sin embargo, Livio volvería hacer referencia a este ilustre varón y en ese caso sí que habla de que era el tío materno de Virginia (Liv., Ab urb. cond., III, 54, 11).

${ }^{27}$ La versión ofrecida por Dionisio es más amplia y con algunas alteraciones en el orden de los acontecimientos de los hechos con respecto a la trama expuesta por Livio (Cf. Dion. Hal., Ant. Rom., XI, 33, 1-6; 34, 1-6; 35, 1-5; 36, 1-5; 37, 1-3).

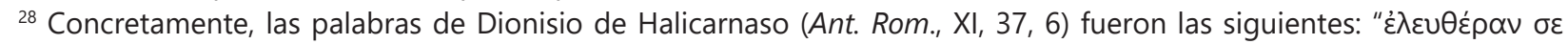

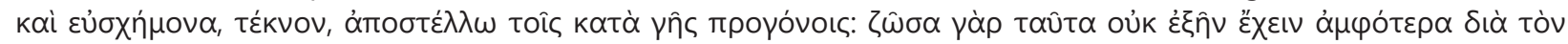
túpavvov" (Libre y virtuosa te envío, hija, a tus antepasados bajo tierra; pues viva no podías tener ambas cosas por
} 
se dirigió a Apio culpándole de lo sucedido y lo maldijo a él y a toda su estirpe (Liv., $A b$ urb. cond., III, 48, 5-6). Se ordenó que fuera apresado Virginio, pero éste escapó gracias a la ayuda de sus amigos. Icilio y Numitorio mostraron el cuerpo sin vida de Virginia para que todas las personas congregadas fueran testigos de lo que había sucedido (Liv., $A b$ urb. cond., III, 48, 6-8; Dion. Hal. Ant. Rom. XI, 28, 1-5). Livio sentencia que todo lo ocurrido era a consecuencia de la belleza de la joven, además de por la necesidad a la que se vio abocado su padre (Liv., Ab urb. cond., III, 48, 7-8).

\section{De puella a mujer virtuosa: una educación diferenciada}

Para hablar de la educación en la antigua Roma tenemos que aludir al mundo griego. Se creía que en el pensamiento helenístico se encontraban las bases fundamentales de los principales preceptos desarrollados en el mundo romano (MARROU, 2004, p. 314). Sin embargo, sí que podemos observar una contraposición entre ambas culturas. Mientras que en Grecia innovaron con el paso de los siglos, los romanos por el contrario se resistieron a salir de los dictados marcados por los mores maiorum. Roma no escapó del ideal colectivo que mantuvo al individuo al servicio del Estado (MARROU, 2004, p. 299-300). Fue precisamente a consecuencia de esos valores anquilosados en la tradición cuando a partir del siglo II a.C. se produjo una "crisis" identitaria en la que se alzaron voces críticas ante las nuevas formas educativas que imperaban en Roma. Esta aseveración que fue argumentada por Marrou ha sido actualmente matizada. Parece que la excesiva dependencia de los preceptos griegos no fue tal y como se creía (CORBEILL, 2001, p. 262-263). De hecho, la educación romana podríamos decir que estuvo estrechamente ligada a la propia historia de Roma, así como a la grandeza de sus primeros habitantes. Se caracterizó la educación romana por ser distinta a la griega en su forma, pues mientras que en Roma imperó el "utilitarismo" que siempre caracterizó su pensamiento, en el mundo heleno terminaría siempre por imperar un carácter más teórico (HORSTER, 2011, p. 84). Incluso, la base fundamental de la educación también fue distinta. Siempre se ha dicho que la ciudad, la polis, era la maestra de sus habitantes (Semon., fr., 53). Por el contrario en Roma la familia fue el sustrato principal donde se instruían las primeras competencias sociales y éticas (FRASCA, 1991, p. 14).

culpa del tirano. Mientras que las palabras de Livio fueron: "Hoc te uno qui posum "ait", modo, filia in libertatem vindico" (Hija, te doy la libertad de la única forma que puedo" (Liv., Ab urb. Cond., 48, 5). Didoro de Sicilia no menciona ningún discurso de Virginio, aunque sí que alude que tomó el padre de Virginia la determinación de asesinarla para librarla de una segura violación (Dio. Sic., Hist., XII, 24, 4-5). 
Entre los problemas fundamentales estaría que en sensu stricto era difícil establecer una división entre hombres y mujeres. Lo poco que conocemos, transmitido por las fuentes históricas y jurídicas, no permite establecer una diferenciación demasiado perfilada (BEST, 1970, p. 199; MALAVÉ OSUNA, 2018, p. 373). A ello tenemos que sumar que los datos siempre están haciendo referencia a las clases sociales privilegiadas, ya que posiblemente los sectores más vulnerables ni tan siquiera tuvieron el derecho de acceder a una educación que excediera el ámbito doméstico. Conocemos los niveles educativos, lo que no sabemos con exactitud fueron los preceptos que se marcaban en el ambiente familiar. Además, dependiendo de la época la situación pudo variar. Por ejemplo, durante la Monarquía y la República ésta se reducía prácticamente a la domus. A ello tendríamos que asumir que, la misma crítica que se produjo acerca del desconocimiento del ámbito femenino por no ser atractivo para los autores clásicos, también se repite en este caso. La educación y las etapas formativas de los más pequeños tampoco eran del interés general de los autores grecolatinos y aquellas fases que eran descritas, que se reducían al ámbito de la retórica, solo podían acceder los varones (CONESA NAVARRO; GONZÁLEZ FERNÁNDEZ, 2015, p. 96). Por su parte, la formación de las niñas se limitaba a recibir instrucción por algún miembro femenino de la familia para ser buenas esposas, madres ejemplares, chicas cariñosas y amigas de las otras mujeres que tenían similar rango (GUILLÉN, 2009, p. 324; CONESA NAVARRO; GONZÁLEZ FERNÁNDEZ, 2015, p. 100-101). Junto a estas responsabilidades, el tejido de la lana era fundamental para ellas, pues era la distinción de trabajo manual por excelencia, ya visto en texto angulares del pensamiento occidental, como Penélope en la Odisea, pasando por otros de impronta romana como la comentada Lucrecia o la virtuosa Claudia, referida en la introducción. Por tanto, siempre que hablemos de educación en el mundo romano tiene que ser tomada con cautela, pues además de no conocerse en su sentido amplio los conocimientos que recibieron niños y niñas, también existirían diferencias en los preceptos dados, dependiendo del espacio temporal y geográfico en el que nos movamos.

Ahora bien, lo que sí que podemos intuir es que en el ámbito doméstico las mujeres y concretamente las madres, tuvieron un papel destacado. Este aspecto no fue algo exclusivo del mundo clásico, sino que en las sociedades donde el pensamiento patriarcal marcó una diferenciación de espacios y tareas, es lógico pensar que mientras ellas se dedicaban a enseñar a los más jóvenes el lenguaje, además de otras tareas, los varones se encontraban inmersos en actividades relacionadas con la agricultura o la caza. Por tanto, eran ellas las que conocían y transmitían a sus hijos la historia primitiva de su pueblo (VILLEGAS GIRALDO, 2018, p. 183-184). Esta visión estereotipada sí que podemos decir 
que se dio en todos los ambientes y lugares, adquiriendo una dimensión mayor cuando se intentaba formar a un varón para la carrera política. ${ }^{29}$

Sobre la educación femenina y el recorrido educacional que debían recorrer las niñas para ser auténticas matronas, ha sido estudiado entre otros por Hemelrijk (1999), cuya obra constituye un referente esencial en la materia. Su trabajo abarca un período dilatado de la Historia de Roma, desde la República, con Cornelia, hasta Julia Domna. Sin embargo, como puede observarse a partir del título de su obra, solo se encargó del análisis de las mujeres de la elite social romana. Posiblemente pueda parecer un estudio parcial, sin embargo, en él se aúnan todos los postulados concernientes a la educación femenina de la Antigüedad. Como se ha indicado, es prácticamente imposible conocer con exactitud los conocimientos transmitidos a las mujeres de las clases serviles. Pese a todo, los niveles inferiores comenzaban en el ámbito doméstico donde los más pequeños se encontraba bajo la vigilancia y cuidados femeninos, principalmente la madre, aunque también cabía la posibilidad de la presencia de nodrizas, esclavas y alguna que otra consejera (LÓPEZ GRÉGORIS, 2014, p. 81; CONESA NAVARRO, 2018, p. 147). Sin embargo, posiblemente en torno a la mitad del siglo III a.C., llegaron ciudadanos griegos que fueron empleados para poder enseñar a los hijos de la élite una educación bilingüe, además de su cultura. Principalmente estos recién llegados eran libertos, nodrizas o pedagogos. La importancia de una educación bilingüe fue tal que, incluso Catón, considerado como uno de los críticos más fuertes ante la influencia helena en Roma, reconsideró sus postulados y para la formación de su hijo contrató a un pedagogo griego (Plut. Cat. Ma. 20; CORBEILL, 2001, p. 269).

A partir de los siete años se abandonaba la esfera lúdica y domestica y comenzaba la etapa escolar. En este caso, tomaba el relevo la vigilancia paterna y se ingresaba en las escuelas. En esas primeras etapas los centros escolares eran mixtos. Los conocimientos impartidos se reducían a aspectos básicos de lectura, escritura y aritmética impartidos por un ludi magister o litterator (LÓPEZ GRÉGORIS, 2014, p. 81-82; LEAS; STRUBBE, 2017, p. 70). Además de no existir una diferenciación de sexos, parece que las personas de las clases sociales más bajas también eran instruidas. Cuando los padres consideraban que habían recibido una formación suficiente, podían ser obligadas a abandonar el sistema educativo. Los conocimientos básicos adquiridos en ocasiones eran tan mínimos, que no se dio una gran diferencia entre aquellas niñas que habían ido a la escuela de las que no.

\footnotetext{
${ }^{29}$ Así entre otras, lo dejó claro Cid López (2001, p. 22): "La primera etapa de la vida transcurría siempre en los espacios domésticos, y en los estudios históricos han interesado más las cuestiones públicas en detrimento de las privadas, al menos hasta hace poco tiempo. Tal situación influyó para que conozcamos mejor a los niños y aristócratas frente a las niñas, pues, aunque criados en el hogar, los primeros estaban destinados a cumplir un papel relevante en la sociedad y en los asuntos cívicos; de igual modo, la infancia de las clases populares no resulta fácil de reconstruir".
} 
En porcentajes, parece que entre un 10 ó 15\% del total de la población fue letrada (LAES; STRUBBE, 2017, p. 99). Una vez que se cumplían los once años se pasaba a dos niveles más hasta completar la formación académica reglada, cuyo último nivel por lo general no se les permitía a las mujeres participar. Por supuesto esta estructura tan rígida pudo tener matices, por lo que tiene que ser tomada siempre con precaución. ${ }^{30} \mathrm{Sin}$ embargo, pese a la férrea estructura educativa romana que se ha tendido a describir y estudiar, salvo a excepción de algún decreto, ya de época imperial como fue en el período de Vespasiano o de algún otro emperador, en Roma, independientemente de la época que estemos hablando, no existió un sistema educativo reconocido y estructurado que fuera amparado y reconocido por la legislación, ni tampoco existió un control sobre las escuelas (CORBEILL, 2007, p. 70; VALIENTE GARCÍA DE CARPIO, 2017, p. 105).

De igual forma se tiene constancia de que una parte reducida de la élite femenina recibió conocimientos más amplios. Esto se debía sin duda a que era aconsejable que las mujeres que solían desposarse con varones entre ocho y diez años mayores que ellas, fueran diestras en artes y en el lenguaje para acompañar a sus maridos en sus carreras políticas (D’AMBRA, 2007, p. 62). Los estudios que realizaban las mujeres, más allá de los aspectos básicos de la escritura y la lectura, estaban relacionados con la filosofía ${ }^{31}$, poesía ${ }^{32}$, la música, la danza o el canto ${ }^{33}$. A finales de la República y ya en época imperial se observó cierta preocupación por la instrucción de las mujeres especialmente las casadas. La afluencia de riqueza en Roma, junto con la introducción de la literatura helenística en los círculos más exquisitos de la sociedad romana, permitió que la retórica también fuera accesible para las mujeres de la alta sociedad. Somos conscientes que fueron casos puntuales y, lógicamente, todos ellos estaban relacionados con grandes matronas de la aristocracia como fueron Hortensia, que llegó a pronunciar un discurso de gran calado en el foro, o Cornelia (CID LÓPEZ, 2001, p. 36-37). A propósito de estas últimas, Quintiliano en su obra, De Institutiones de oratoria, hace un repaso a diferentes personajes destacados de la Historia de Roma. Todos ellos se caracterizaron, según el autor de Calahorra, porque sus cualidades fueron producto de la formación recibida por unos padres preocupados y con dotes oratorias. Los ejemplos que expuso fueron los de los hermanos Graco, cuya

\footnotetext{
${ }^{30}$ Los otros dos niveles educativos son los siguientes: Durante el segundo se impartían conocimientos poéticos, geográficos, literarios y retóricos, enseñados por un grammaticus cuyas edades comprendidas eran de los 11 a 13 años aproximadamente. La tercera y última fase iba desde los catorce a los dieciséis años. Era cuando se terminaban a perfilar los últimos conocimientos de retórica bajo la supervisión de un rethor. Finalizaba con la toma de la toga uirilis por los varones (HEMELRIJK, 1999, p. 16-18; CONESA NAVARRO; GONZÁLEZ FERNÁNDEZ, 2015, p. 97-98).

${ }^{31}$ Musonio (Fragmenta, III) y Macr. (Sat., VII, 1, 5-7).

${ }^{32}$ Ovidio (Ars Amatoria, III, 340-345).

${ }^{33}$ Macr. (Sat., III, 14, 5-6) y Ov. (Ars, III, 315-320, 349-352; Rem., 351-354).
} 
formación se debía a Cornelia su madre, Lelia de su padre Cayo y Hortensia cuyas dotes oratorias provenían de su padre Hortensio (Quint., Inst., l, 1, 6).

El caso de Hortensia es más explícito, pues fue ella misma la que tuvo la valentía de hablar en el foro (ORTUÑO PÉREZ, 2015, p. 4; ORTUÑO PÉREZ, 2016, p. 370). Sin embargo, mientras que no se tiene constancia de que Cornelia pronunciara ningún discurso, sí que sabemos que fue la encargada de enseñarle a sus hijos los honores patrios que defendieron cuando fueron tribunos de la plebe. Lo mismo se podría decir de Aurelia y Atia, progenitoras de César y Augusto, que fueron ensalzadas por Tácito (Dialogus de oratoribus, 28, 6-7; CID LÓPEZ, 2001, p. 23-24). Además, se tiene constancia que la fuerte carga helénica en las reformas emprendidas por los hermanos Graco se debió a que su madre fue instruida en gramática griega que dominaba con fluidez y esta marcó una gran influencia sobre sus hijos. Eso sin contar que estuvo rodeada de un círculo de eruditos helenos con los que conversaba en su villa en Miseumn. Se conoce su capacidad oratoria además de que sus cartas, que fueron conservadas (HEMELRIJK, 1999, p. 21-22). Lo mismo podríamos decir sobre la emperatriz Julia Domna que junto con Cornelia fue de las pocas mujeres de la Historia de Roma que recibió formación retórica. En un momento dado se rodeó de un círculo de intelectuales cuando, supuestamente, fue apartada de la esfera pública por el excesivo protagonismo del prefecto del pretorio de Septimio Severo, Cayo Fulvio Plauciano (D.C. 76 (77), 15, 6-7; GONZÁLEZ FERNÁNDEZ; CONESA NAVARRO, 2014, p. 42-43; LEAS; STRUBBE, 2017, p. 100).

Sobre esta cuestión, Hemelrik puntualizó que las referencias sobre la formación de las mujeres adultas, en su mayoría se reduce a aquellas que pertenecieron a la aristocracia y que estaban casadas. Se debía a que, por su riqueza económica, además de por sus deberes religiosos y su influencia política, aunque fuera de manera indirecta, las hacía estar menos ocultas. Eso no quiere decir que el conocimiento sobre ellas sea fácil, ya que los textos que hablan sobre la educación de estas distinguidas matronas son sesgados y difíciles de interpretar. La formación que recibieron en su mayoría provenía o bien de sus esposos, o a partir de la contratación de algún instructor privado. También la asistencia a cenas y eventos públicos fue un complemento, pues les permitía conversar y relacionarse con los eruditos de la época (HEMELRIJK, 1999, p. 16).

Aunque sea de manera somera, es necesario mencionar que la exclusión de la mujer en los asuntos civiles y políticos, tal y como ha indicado Pavón (2015), venía auspiciada por dos principios fundamentales. Por un lado, estaba la costumbre de los antepasados, los denominados mores maiorum, que, desde los orígenes habían predispuesto a los varones a ser los encargados de llevar a cabo todos los asuntos de la espera pública y política. Sin embargo, otro aspecto de vital importancia imposibilitaba a las mujeres de 
ejercer actividades ajenas a las del ámbito doméstico y en este caso, venía auspiciado por la propia naturaleza. Diferentes autores han expresado calificativos sobre las mujeres a la hora de definirlas: leuitas animi ${ }^{34}$, infirmitas sexus, frugalitas o sexus inbecillitatem, este último calificativo dado por Ulpiano (Digestum, 16, 1, 2, 2-3; GÓMEZ BUENDÍA, 2015, p. 152; BRAVO BOSCH, 2017a, p. 35; BRAVO BOSCH, 2017b, p. 1021, 1023). La debilidad de espíritu femenina las hacía incapaces de controlar sus pasiones y en un continuo estado de inmadurez que las imposibilitaba de tener decisiones propias. Por tanto, se insistía que siempre debían estar bajo la atenta mirada masculina (PAVÓN, 2015, p. 118). Lo que sí que podemos advertir es que a las jóvenes romanas se las educaba desde niñas para que supieran cumplir los deberes que debían desempeñar una vez que fueran adultas (GUILLÉN, 2009, p. 324). Por tanto, aunque pueda parecer una obviedad, es necesario recordar que la función primordial a la que todas mujeres estaban destinadas no solo en Roma, sino en cualquier civilización antigua, era la función reproductora (FLORES SANTAMARÍA, 1986, p. 217).

\section{Recapitulaciones}

Autores del siglo I a.C. como Cicerón, Horacio o el propio Salustio, atribuyeron a las luchas de las distintas facciones nobiliarias las principales causas de la crisis de la República. Palabras como auaritia, luxus, cupiditas, libido, abundantes noluptates entre otras, fueron expresadas por el propio Tito Livio. En un deseo de describir cómo los tiempos pasados siempre fueron mejores, se forjaron narraciones míticas que pueden ser cuestionadas (JOSHEL, 2002, p. 170) pero que sin duda dieron identidad al Imperio.

En los personajes legendarios de Lucrecia y Virginia se encarnaban las consecuencias que tuvo el poder patriarcal en la época romana, pero, a su vez se mostraron las virtudes y cualidades que tenían que tener todas las mujeres romanas. La belleza fue el desencadenante de los actos que recayeron sobre ellas. La violencia fue una constante en muchos relatos de la prosa y literatura romana. Infinidad de situaciones donde la sumisión y la dominación fue una constante y casi siempre, ejercida sobre las mujeres, muestran los diferentes roles de género que imperaron en la sociedad antigua. Estas narraciones constituyeron verdaderos exempla para los niños romanos, en las que se mostraban a ciertas mujeres como fueron Lucrecia y Virginia en situaciones de extrema dureza. Con sus historias se mostraba además de la dominación masculina anteriormente

\footnotetext{
${ }^{34}$ Gaio (Instituta, 1, 144).
} 
mencionada, la importancia que tenía la familia y lo transcendental que suponía preservar el honor de la gens (DIXON, 2007, p. 47; CORBEILL, 2010, p. 226-227).

En ambos relatos podemos observar que se reproduce el mismo esquema. Una mujer, ya fuera casada o prometida, que destaca por su gran belleza y que precisamente sería junto con su actitud intachable los desencadenantes de su perdición. Sus vidas cambiarían fundamentalmente por culpa de un varón respetable en Roma. Ambas se mostraron impecables en conducta, nada reprochable, sin embargo, sus vidas finalizarían y sobre ellas recayó todo el mal realizo tanto por Sexto Tarquinio como por Apio Claudio. Entre las principales diferencias estaría que en el relato de Lucrecia el hijo del rey conseguiría mantener relaciones sexuales con ella tras ser presionada con la posibilidad de deshonor, mientras que en Virginia el decenviro no llegó a poseerla porque su padre, intuyendo el desenlace, se adelantó y puso fin a la vida de su hija, dándole la única libertar que en ese momento podía. Más allá de las historias en sí, lo que nos interesa sería saber las motivaciones que llevaron a Livio y al resto de autores clásicos para que centraran su atención en estas mujeres. Los autores clásicos hablaron de estas mujeres porque encarnaban el espíritu fiel a las tradiciones. Esta visión se pretendía transmitir a las futuras generaciones. Por tanto, lo importante no fue la veracidad de las vidas de ellas, ni tan siquiera nos interesaría saber con exactitud si Virginia y Lucrecia fueron reales, sino la función pedagógica y educativa que se hizo a través de sus vidas. Los finales terribles de ambas simbolizaron el enorme valor que los romanos dieron a la castidad, como bien ha comentado Cid López (2015). Independientemente de lo sucedido, no solo fueron víctimas de los abusos masculinos, sino también de las normas y leyes de la antigua Roma.

Las mujeres desde niñas, pese a compartir espacios tanto en el ámbito domestico como en las escuelas, tuvieron unos roles diferenciados, en los que las madres actuaron como grandes maestras y forjadoras de los mores maiorum. Ellas fueron las encargadas de formar a los futuros ciudadanos de Roma, por lo que el conocimiento de la historia primitiva de la urbs fue importante para que sus ciudadanos no olvidaran sus logros. Las niñas desde pequeñas fueron también educadas para el hogar y el matrimonio. Al margen de sus tareas, también tenían que ser intachables, por lo que el honor familiar y la supeditación a la voluntad masculina fue una constante. Los ejemplos de la mujer de Tarquinio Colatino y la hija de Virginio, además de files mujeres fueron respetuosas al honor familiar hasta el extremo. Por tanto, creemos que ambas mujeres fueron transcendentales para las mujeres en Roma, independientemente de la época que tratemos, pues en ellas se encarnaban el ideal de virtud y honor que se pretendía transmitir a las sucesivas generaciones. 


\section{Referências}

ABAD ARENAS, E. La ruptura de la promesa de matrimonio. Madrid: Marcial Pons, 2014. ÁLVAREZ, Ma. C.; IGLESIAS, R. Mª La mujer en Roma. Scripta Fulgentina, n. 8, v. 15-16, p. 49-66, 1998.

BAEZA ANGULO, E.; BUONO, V. Contaminaciones entre la matrona ideal y la puella elegíaca. Emérita, n. 81, v. 2, p. 263- 293, $2013 a$.

BAEZA ANGULO, E.; BUONO, V. La solitudine domestica della matrone elegiache. Ágora, n. 15, p. 33-49, 2013 b.

BAUMAN, R. A. The rape of Lucretia, Quod metus causa and the criminal law. Latomus, n. 52, v. 3, p. 550-566, 1993.

BEST, E. E. Cicero, Livy and educated Roman women. The Classical Journal, n. 65, v. 5, p. 199-204, 1970.

BONNER, S. F. La educación en la Roma Antigua. Barcelona: Herder, 1984.

BRAVO BOSCH, Ma . J. El mito de Lucrecia y la familia romana. In: RODRÍGUEZ LÓPEZ, R.; BRAVO BOSCH, Ma . J. (Ed.). Mulier: algunas historias e instituciones de Derecho Romano. Madrid: Dykinson, 2013, p. 19-36.

BRAVO BOSCH, Ma . J. Mujeres y símbolos en la Roma republicana: análisis jurídico-histórico de Lucrecia y Cornelia. Madrid: Dykinson, 2017a.

BRAVO BOSH, Ma. J. Levitas animi. Glossae. European Journal of Legal History, n. 14, p. 1008-1031, 2017b.

CANTARELLA, E. Los suplicios capitales en Grecia y Roma: orígenes y funciones de la pena de muerte en la Antigüedad Clásica, Madrid: Akal, 1991.

CENERINI, F. La donna romana: modelli e realtà. Bologna: II Mulino, 2009.

CID LÓPEZ, R. Ma . La educación de la niña romana: de puella a matrona docta. In: ALFARO

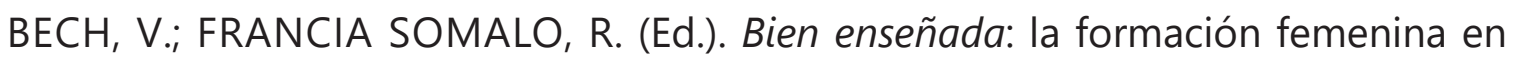
Roma y el occidente romanizado. Málaga: Universidad de Málaga, 2001, p. 21-44.

CID LÓPEZ, R. Ma . Las matronas y los agmina mulierum en la Roma Antigua: del matriotismo a la protesta. In: MARTíNEZ LÓPEZ, C.; UBRIC RABANEDA, P. (Ed.). Cartografías de género en las ciudades antiguas. Granada: Universidad de Granada, 2017, p. 207-231.

CID LÓPEZ, R. Ma . Las silenciosas mujeres de la Roma antigua: revisiones desde el género y la historia. In: DOMíNGUEZ ARRANZ, A.; MARINA SÁEZ, R. Ma . (Ed.) Género y enseñanza de la Historia. Madrid: Sílex, 2015, p. 187-212. 
CID LÓPEZ, R. Ma . Mujeres y actividades políticas en la República: las matronas rebeldes y sus antecesoras en la Roma Antigua. In: DOMíNGUEZ ARRANZ, A. (Ed.) Mujeres en la Antigüedad Clásica. Madrid: Sílex, 2010, p. 125-151.

CONESA NAVARRO, P. D. Estudios sobre mujeres de la Antigua Roma: estado de la cuestión, problemas y progreso científico en un campo histórico consolidado. Minius, n. 24, p. 205-226, 2016.

CONESA NAVARRO, P. D. Madres sustitutas: una perspectiva comparada de las nodrizas en la Antigua Roma y en la sociedad contemporánea. In: BRAVO BOSCH, Ma. J.; VALMAÑA OCHAÍTA, A.; RODRÍGUEZ LÓPEZ, R. (Ed.). No tan lejano: una visión de la mujer romana a través de temas de actualidad. Valencia: Tirant lo Blanch, 2018, p. $145-169$.

CONESA NAVARRO, P. D.; GONZÁLEZ FERNÁNDEZ, R. De salvajes a domesticadas: aproximación a un ensayo sobre la justificación de la condición femenina en el mundo romano. Revue des Études Anciennes, n. 117, 1, p. 87-108, 2015.

CONESA NAVARRO, P. D.; GONZÁLEZ FERNÁNDEZ, R. Mors honesta: suicidas y muertes inducidas de mujeres en la Antigua Roma. In: RODRÍGUEZ LÓPEZ, R.; BRAVO $\mathrm{BOSCH}, \mathrm{M}^{\mathrm{a}}$. J. (Ed.). Mujeres en tiempos de Augusto: realidad social e imposición legal. Valencia: Tirant lo Blanch, 2016, p. 585-609.

CORBEILL, A. Education in the Roman Republic: creating traditions. In: LEE TOO, Y. (Ed.). Education in Greek and Roman Antiquity. Leiden: Brill, 2001, p. 261-287.

CORBEILL, A. Gender studies. In: BARCHIESI, A.; SCHEIDEL, W. (Ed.). The Oxford Handbook of Roman Studies. Oxford: Oxford University Press, 2010, p. 220-233.

CORBEILL, A. Rhetorical education and social reproduction in the Republic and Early Empire. In: DOMINIK, W.; HALL, J. (Ed.). A Companion to Roman rhetoric. London: Wiley-Blackwell, 2007, p. 69-82.

D’AMBRA, E. Roman women. Cambridge: Cambridge University Press, 2007.

DE LA ROSA CUBO, C. Livia: religión y poder en la época imperial. In: CERRADA JIMÉNEZ, A. I.; SEGURA GRAÍÑO, C. (Ed.). Las mujeres y el poder: representaciones y prácticas de vida. Madrid: Asociación Cultural Al-Mudayna, 2000, p. 53-64.

DIXON, S. D. Reading Roman women. London: Bloomsbury, 2007.

DIXON, S. D. The Roman family. London: The Johns Hopkins University Press, 1992.

DONALDSON, I. The rapes of Lucretia: a myth and its transformations. Oxford: Oxford University Press, 1982.

FERNÁNDEZ MARTÍNEZ, C. Entre la literatura y la vida: el elogio fúnebre a la mujer romana. Lección inaugural leída en la solemne apertura del curso académico 20162017 en la Universidad de Sevilla, Sevilla, 2016. 
FLORES SANTAMARÍA, P. Las jóvenes romanas: una educación para el matrimonio. In: GARRIDO GONZÁLEZ, E. (Ed.). La mujer en el mundo antiguo. Madrid, 1986, p. 217-224.

FRASCA, R. Donne e uomini nell'educazione a Roma, Firenze: La Nuova Italia, 1991.

FRASCA, R. Educazione e formazione a Roma: Storia, testi, immagini. Bari: Dedalo, 1996.

FUENTES MORENO, F. Lucrecia. In: POCIÑA PÉREZ, A.; GARCÍA GONZÁLEZ, J. Må. (Ed.). En Grecia y Roma, III: mujeres reales y ficticias. Granada: Editorial Universidad de Granada, 2009, p. 97-113.

GALLEGO FRANCO, H. Crónicas de una relación ilícita: mujeres, acción política e historiografía en Hispania tardoantigua. In: DOMÍNGUEZ ARRANZ, A.; MARINA SÁEZ, R. Ma . (Ed.). Género y enseñanza de la Historia: silencios y ausencias en la construcción del pasado. Madrid: Sílex, 2015, p. 315-343.

GARDNER, J. F. Women in Roman law and society. Indianapolis: Indiana University Press, 1991.

GÓMEZ BUENDÍA, C. "Exceptio utilis" en el procedimiento formulario del derecho romano. Madrid: Dykinson, 2015.

GONZÁLEZ FERNÁNDEZ, R.; CONESA NAVARRO, P. D. Plauciano: la amenaza de la domus severiana. Potestas, n. 7, p. 27-50, 2014.

GUILLÉN, J. "Urbs" Roma: construcción y desarrollo de la sociedad. Salamanca: Sígueme, 2009. Tomo IV.

HEMELRIJK, E. A. Hidden lives, public personae: women and civic life in the Roman West. Oxford: Oxford University Press, 2015.

HEMELRIJK, E. A. Matrona docta: educated women in the Roma élite from Cornelia to Julia Domna. London: Routledge, 1999.

HERREROS GONZÁLEZ, C.; SANTAPAU PASTOR, Ma. C. Prostitución y matrimonio en Roma: uniones de hecho o de derecho. Iberia, n. 8, p. 89-111, 2005.

HORSTER, M. Primary education. In: PEACHIN, M. (Ed.). The Oxford Handbook of social relations in the Roman World. Oxford: Oxford University Press, 2011, p. 84-100.

IRIARTE GOÑI, A. De amazonas a ciudadanos: pretexto ginecocrático y patriarcado en la Grecia Antigua. Madrid: Akal, 2002.

JOSHEL, S R. The body female and the body politic: Livy's Lucretia and Verginia. In: MCCLURE, L. K. (Ed.). Sexuality and gender in the Classical World: readings and sources. Oxford: Wiley-Blackwell, 2002, p. 164-190.

KNAPP, R. C. Los olvidados de Roma: prostitutas, forajidos, esclavos, gladiadores y gente corriente. Barcelona: Ariel, 2011. 
KRAUS, C. S. Historiography and biography. In: BARCHIESI, A.; SCHEIDEL, W. (Ed.). The Oxford Handbook of Roman Studies. Oxford: Oxford University Press, 2010, p. 403419.

LAES, CH.; STRUBBE, J. Youth in the Roman Empire: the young and the restless years? Cambridge: Cambridge University Press, 2017.

LEÓN LÁZARO, G. La educación en Roma. Anuario Jurídico y Económico Escurialense, n. XLVI, p. 469-482, 2013.

LÓPEZ GRÉGORIS, R. La infancia en Roma. "Mientras viví, jugué". In: HERNÁNDEZ CRESPO, R.; DOMÍNGUEZ MONEDERO, A. J. (Ed.). Las edades del hombre: las etapas de la vida entre griegos y romanos. Madrid: Sociedad Española de Estudios Clásicos, 2014, p. 69-91.

MALAVÉ OSUNA, B. Figuras femeninas en educación: mujeres que instruyen y niñas que aprenden en Roma. In: BRAVO BOSCH, Mª. J.; VALCAÑA OCHAÍTA, A.; RODRÍGUEZ LÓPEZ, R. (Ed.). No tan lejano: una visión de la mujer romana a través de temas de actualidad. Valencia: Tirant lo Blanch, 2018, p. 339-374.

MARCELO MARTINO, L. Reescribiendo la moral de los ancestros: las costumbres. ¿Intachables? De los maiores en Tito Livio. Ágora, n. 11, p. 49- 69, 2009.

MARROU, H.-I. Historia de la educación en la Antigüedad. Madrid: Akal, 2004.

MARTÍNEZ LÓPEZ, C. Con nombre de mujer: memoria de las mujeres en la arquitectura de las ciudades romanas. In: MARTíNEZ LÓPEZ, C.; UBRIC RABANEDA, P. (Ed.). Cartografías de género en las ciudades antiguas. Granada: Universidad de Granada, 2017, p. 105-131.

MAYOR, A. Amazonas: guerreras del mundo antiguo. Madrid: Desperta Ferro, 2017.

MOLAS FONT, M. D. Alteridad y género en el mito de las amazonas. In: CID LÓPEZ, R. Ma ; GARCÍA FERNÁNDEZ, E. (Ed.). Debita verba II: Estudios en homenaje al profesor Julio Mangas Manjarrés. Oviedo: Ediciones de la Universidad de Oviedo, 2013, p. 551-566.

MOSQUERA SOUTO, M. E. El concepto de mujer ideal y el matrimonio en las cartas de Plinio el Joven. Gallaecia, n. 19, p. 251-268, 2000.

MUÑOZ CATALÁN, E. Crisis en las promesas de matrimonio: del vínculo jurídico de los esponsales romanos a la Carta de Arras desde la España Altomedieval. lus Fugit, n. 17, p. 352-353, 2011-2014.

ORTUÑO PÉREZ, Ma . E. Hortensia: su discurso contra la imposición fiscal femenina. In: RODRÍGUEZ LÓPEZ, R.; BRAVO BOSCH, Ma . J. (Ed.). Mujeres en tiempos de Augusto: realidad social e imposición legal. Valencia: Tirant lo Blanch, 2016, p. 367-400. 
ORTUÑO PÉREZ, Ma . E. La oratoria femenina y la fiscalidad en la segunda mitad del siglo I a.C.: un caso singular. Revista General de Derecho Romano, n. 25, p. 1-30, 2015.

PAVÓN, P. La mujer en la religión romana: entre la participación y la marginación. In: FerRer AlBeldA, E.; PeREIRA DelGADO, A. (Coord.). Hijas de Eva: mujeres y religión en la Antigüedad. Sevilla: Universidad de Sevilla, 2015, p. 115-141.

PAVÓN, P. Valerio Máximo y la asimetría sexual en la severidad del castigo. Latomus, n. 67, v. 3, p. 679-691, 2008.

PERRY, M. J. Gender, manumission and the Roman freedwoman. Cambridge: Cambridge University Press, 2004.

PHILLIPS, J. Current research in Livy's first decade: 1959-1979. Aufsteig und Niedergang der Römischer Welt, n. 30, v. 2, p. 998-1054, 1982.

POMEROY, S. B. Diosas, rameras, esposas y esclavas: mujeres en la Antigüedad Clásica. Barcelona: Akal, 2004.

SALLER, R. P. "Familia, Domus", and the Roman conception of the family. Phoenix, n. 38, V. 4, p. 336-355, 1984.

STEVENSON, T. Women of Early as "Exempla". In: LIVY. "Ab Urbe Condita", Book 1. The Classical World, n. 104, v. 2, p. 175-189, 2011.

STRONG, A. K. Prostitutes and matrons in the Roman World. Cambridge: Cambridge University Press, 2016.

VALIENTE GARCÍA DEL CARPIO, H. "La letra con sangre entra": violencia en las aulas en la antigua Roma. In: BRAVO, G.; GONZÁLEZ SALINERO, R. (Eds.). Formas y usos de la violencia en el mundo romano. Madrid, p. 105-112.

VILLEGAS GIRALDO, P. A. Dignidad de la mujer y multiculturalismo. Femeris, n. 3, v. 1, p. 183-194, 2018. 